\title{
Distribusi dan Pemetaan Varian-Varian Bahasa Bali di Kabupaten Sumbawa dan Sumbawa Barat
}

\author{
Siti Roudloh*)
}

\begin{abstract}
Abstrak
Penelitian ini mengkaji distribusi dan pemetaan varianvarian bahasa Bali di Kabupaten Sumbawa dan Kabupaten Sumbawa Barat dengan menggunakan pendekatan dialektologi diakronis.

Dalam penelitian ini ada empat daerah pengamatan, yaitu 1). Dusun Mekar Sari, Desa Sepayung, Kecamatan Pelampang, 2). Kelurahan Uma Sima, Kecamatan Sumbawa, 3). Desa Rhee Kecamatan Rhee, dan 4). Dusun Kokarlian, Desa Poto Tano, Kecamatan Seteluk.

Bahasa Bali yang ada di Kabupaten Sumbawa dan Kabupaten Sumbawa Barat mempunyai empat dialek, yaitu Dialek Mekar Sari (DM), Dialek Uma Sima (DU), Dialek Rhee (DR), dan Dialek Kokarlian (DK). Adapun mengenai hubungan kekerabatan, DM memiliki hubungan kekerabatan yang dekat dengan DU, DR memiliki hubungan kekerabatan yang dekat dengan DM dan DU, sedangkan DK memiliki hubungan kekerabatan yang dekat dengan DM.
\end{abstract}

Kata Kunci: varian-varian bahasa, dialektometri, kantong bahasa (enklave)

\section{Pengantar}

Keberagaman suku bangsa Indonesia di Indonesia selain terefleksi dari banyaknya budaya dan adat istiadat juga terefleksi dari banyaknya bahasa yang dituturkan oleh berbagai suku bangsa di Indonesia. Untuk mengetahui jumlah bahasa yang ada di Indonesia dan sebaran geografisnya secara pasti perlu dilakukan penelitian terhadap daerah kantong bahasa di berbagai wilayah Indonesia.

Informasi tentang bahasa yang digunakan di NTB dapat disebutkan, antara lain oleh Esser (1938), Salzner (1960), Lembaga Bahasa Nasional (1972), dan Tim Penyusunan Monografi Daerah Nusa

\footnotetext{
*) Sarjana Pendidikan, Pembantu Pimpinan pada Kantor Bahasa Prov. NTB
} 
Tenggara Barat (1977). Menurut Esser (1938) (dalam Herusantoso, dkk.,1987:3), di NTB terdapat tiga bahasa yang masuk kelompok BaliSasak, yaitu bahasa Bali, Sasak, dan Sumbawa dan bahasa Bima, yang masuk kelompok bahasa Bima Sumba. Lebih lanjut, Salzner mengatakan bahwa di Pulau Lombok dan Sumbawa terdapat empat bahasa, yakni bahasa Bali, Sasak, Sumbawa, dan Bima (1960:16). Di samping itu Pusat Pembinaan dan Pengembangan Bahasa menyatakan bahwa di NTB terdapat (1) bahasa Sasak dengan dialek-dialeknya, yaitu (a) bahasa Sasak dialek Pejanggik, (b) bahasa Sasak dialek Selaparang, (c) bahasa Sasak dialek Bayan, (d) bahasa Sasak dialek Tanjung, (e) bahasa Sasak dialek Pujut,(f) bahasa Sasak dialek Sembalun/Sasak Dasan dialek Lengkong, (g) bahasa Sasak dialek Temangu, dan (h) bahasa Sasak dialek Pengantap, serta (2) bahasa Bali Sasak. Di Pulau Sumbawa terdapat (1) bahasa Sumbawa dengan dialek-dialeknya, yaitu (a) bahasa Samawa, (b) bahasa Samawa Batu Rotak(bahasa Samawa Sasak), dan (c) bahasa Samawa Taliwang, serta (2) bahasa Bima dengan dialekdialeknya, yaitu (a) bahasa Bima Komodo, (b) bahasa Bima Donggo, dan (c) bahasa Bima Sangiang.

Di wilayah Pulau Sumbawa, khususnya di Kabupaten Sumbawa dan Kabupaten Sumbawa Barat ditemukan penduduk yang berasal dari Bali yang menggunakan bahasa Bali dalam komunikasi sehari-hari terutama di lingkungan keluarga. Persebaran penduduk Bali ke luar daerah Bali kebanyakan berkaitan dengan program transmigrasi. Salah satu pendorong penyebaran penduduk daerah Bali adalah terjadi tingkat kepadatan penduduk setiap tahunnya secara menyeluruh. Data di tahun 1953--1976 menunjukkan bahwa penduduk daerah Bali telah menyebar dan tinggal menetap di beberapa daerah yang ada di Indonesia. Pada umumnya mereka sebagai transmigrasi spontan maupun transmigrasi 
yang dianjurkan pemerintah. Di tahun 1958--1972 ada 12 daerah provinsi yang dituju transmigran Bali dan salah satunya di Nusa Tenggara Barat berjumlah 1.632 jiwa.

Berdasarkan hasil penelitian yang telah dilakukan ternyata penelitian mengenai distribusi bahasa Bali di Kabupaten Sumbawa Barat dan Kabupaten Sumbawa, terutama yang berkaitan dengan pemetaaan, jumlah penutur, hubungan kekerabatan, dan munculnya variasi lingual yang terdapat pada tiap-tiap bahasa belum diteliti. Oleh karena itu, hal ini sangat menarik untuk diteliti secara tuntas.

Penelitian ini merupakan kajian variasi dialektal, maka metodenya menggunakan pendekatan dialektologi diakronis yang meliputi metode kuantitatif berupa perhitungan dialektometri.

\section{Pembahasan}

\subsection{Deskripsi Unsur-unsur Kebahasaan}

Perbedaan linguistik yang dibicarakan dalam bagian ini mencakup bidang fonologi dan leksikon yang terdapat di antara daerahdaerah pengamatan. Berdasarkan 400 data yang dianalisis telah teridentifikasi sebanyak 279 buah peta perbedaan unsur-unsur kebehasaan yang meliputi kedua bidang di atas. Berikut ini akan dipaparkan beberapa buah contoh.

\subsubsection{Perbedaan Fonologi}

Perbedaan fonologi yang dibicarakan di sini dapat dibedakan atas empat macam, yaitu: korespondensi vokal, variasi vokal, korespondensi konsonan, dan variasi konsonan. Contoh keempat tipe perbedaan fonologi tersebut akan akan diuraikan berikut ini. 


\subsubsection{Korespondensi Vokal}

Berdasarkan data yang terkumpul ditemukan hanya satu korespondensi vokal, yaitu vokal [ə] pada silabe ultima berkorespondensi dengan vokal [a]. Vokal [ə] muncul pada daerah pengamatan 1, sedangkan vokal [a] muncul pada daerah pengamatan 2 dan 4. Contoh:

$$
\begin{aligned}
& \text { [sabəh }]=\square \text { [sabah] 'hujan' } \\
& \text { [bawəq] }=\square \text { [bawaq] 'pendek' }
\end{aligned}
$$

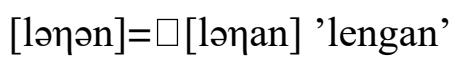

Untuk makna 'hujan' digunakan pula bentuk [hujan], makna 'pendek' digunakan bentuk[endep], dan makna 'lengan' digunakan bentuk [tanan] masing-masing pada daerah pengamatan 3.

\subsubsection{Korespondensi Konsonan}

Untuk korespondensi konsonan ditemukan hanya satu yang berkategori sebagai korespondensi sempurna, sedangkan yang 5 lainnya korespondensi kurang sempurna. Korespondensi sempurna yang dimaksud adalah korespondensi antara :[h] pada posisi antar vokal berkorespondensi dengan [ø]. Konsonan [h] muncul pada daerah pengamatan 4, sedangkan [ø] muncul pada daerah pengamatan 1,2 dan 3. Contoh:

$$
\begin{aligned}
& \text { [baat }]=\square[\text { bahat }] \text { 'berat' } \\
& \text { [poos }]=\square[\text { pəhəs }] \text { 'ludah' }
\end{aligned}
$$

[matanai] $=\square[$ matanahi] 'matahari'

Daerah sebaran korespondensi konsonan ini adalah:

[h] pada daerah pengamatan 4 dan

[ø] pada daerah pengamatan 1,2, dan 3 .

Adapun lima korespondensi konsonan lain yang kurang sempurna dimasukkan dalam variasi konsonan. 


\subsubsection{Variasi Vokal}

Berdasarkan data yang diperoleh, perbedaan fonologi yang berupa variasi vokal yang ditemukan dalam penelitian ini sebanyak lima puluh buah. Contoh:

1. Variasi vokal [ə-ב] [a-i]

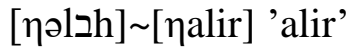

[ə] digunakan pada daerah pengamatan 3

[a-i] digunakan pada daerah pengamatan 4

Selain bentuk-bentuk di atas, makna tersebut juga direalisasikan dengan menggunakan bentuk [mejalan] pada daerah pengamatan 1 dan [məmbah] pada daerah pengamatan 2 .

\subsubsection{Variasi Konsonan}

Berdasarkan data yang diperoleh, variasi konsonan yang ditemukan dalam penelitian ini sebanyak 68 buah. Contoh:

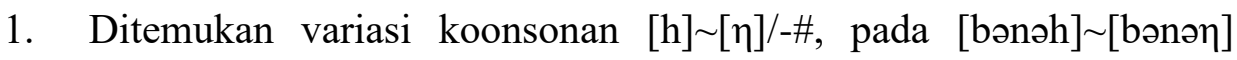
'benar'. Daerah sebaran variasi konsonan tipe ini adalah:

[h] pada daerah pengamatan $1,2,3$

[ $\eta$ pada daerah pengamatan 4

\subsubsection{Perbedaan Leksikon}

Berdasarkan data yang diperoleh dari penelitian, ternyata perbedaan linguistik cukup banyak ditemukan dalam bidang leksikon, di samping perbedaan fonologi serta daerah sebarannya sangat beragam. Namun demikian, dalam bagian ini tidak akan dikemukakan semua perbedaan itu secara satu per satu, melainkan hanya sebagian saja, yang diharapkan dapat memberikan gambaran daerah sebaran perbedaanperbedaan tersebut secara menyeluruh. Perlu dikemukakan pula, bahwa sebagian besar perbedaan leksikon itu berwujud perbedaan yang berupa variasi, contoh. Makna `awan` memunculkan dua varian, yaitu: [awan] 
yang digunakan pada daerah pengamatan: 1 dan 2; [guləm] yang digunakan pada daerah pengamatan: 3 dan 4 .

\subsection{Penentuan Isolek sebagai Dialek dan Subdialek}

Dalam bagian ini akan dilakukan penentuan isolek sebagai dialek atau subdialek. Hal ini dimaksudkan agar diperoleh gambaran yang jelas mengenai hubungan yang terdapat antara isolek yang digunakan pada setiap daerah pengamatan. Untuk mencapai tujuan tersebut, upaya yang dilakukan adalah menghitung jumlah isoglos yang berfungsi menyatukan daerah-daerah pengamatan, yang menampilkan gejala kebahasaan yang serupa. Dengan kata lain, jumlah isogloss yang menyatukan daerahdaerah pengamatan yang menampilkan gejala kebahasaan yang serupa itu dijadikan landasan dalam menentukan isolek sebagai dialek atau subdialek.

Penentuan dialek atau subdialek bahasa Bali di Kabupaten Sumbawa dan Kabupaten Sumbawa Barat dilakukan dengan menggunakan metode kuantitatif, yaitu dialektometri dan metode kualitatif, yaitu inovasi bersama. Kedua metode ini saling melengkapi. Hasil perhitungan menggunakan metode dialektometri dijadikan dasar penentuan isolekisolek menjadi dialek atau subdialek. Akan tetapi, jika bukti kuantitatif ini memisahkan suatu isolek dengan isolek lainnya sebagai bahasa yang berbeda, bukti kualitatif yang berupa inovasi bersama digunakan sebagai bahan pertimbangan penyatuan kembali isolek-isolek tersebut menjadi satu bahasa.

Dengan berpijak pada patokan-patokan yang ditentukan dalam metode penentuan dialek/subdialek, maka dapat dikatakan bahwa bahwa bahasa Bali di Kabupaten Sumbawa dan Kabupaten Sumbawa Barat memiliki 4 dialek yaitu:

1. Dialek Mekar Sari (DM), yaitu daerah pengamatan 1 
2. Dialek Uma Sima (DU), yaitu daerah pengamatan 2

3. Dialek Rhe (DR), yaitu daerah pengamatan 3

4. Dialek Kokarlian (DK), yaitu daerah pengamatan 4

Penentuan 4 dialek diatas didasarkan pada perhitungan dialektometri berikut ini.

\begin{tabular}{|c|c|l|l|}
\hline No & $\begin{array}{c}\text { Daerah yang } \\
\text { dibandingkan }\end{array}$ & \multicolumn{1}{|c|}{ Dialektometri } & Status Isolek \\
\hline 1 & $1-2$ & $\underline{\underline{177} \times 100 \%=63,44 \%}$ & Beda Dialek \\
\hline 2 & $1-3$ & $\underline{279} \times 100 \%=73,11 \%$ & Beda Dialek \\
\hline 3 & $1-4$ & $\underline{279}$ & 279 \\
& $2-3$ & $\underline{200} \times 100 \%=71,32 \%$ & Beda Dialek \\
\hline 4 & 279 & \\
\hline 5 & $3-4$ & $\underline{212} \times 100 \%=75,98 \%$ & Beda Dialek \\
\hline 6 & & $\underline{279}$ & Beda Dialek \\
\hline
\end{tabular}

Berdasarkan perhitungan dialektometri di atas dapat dijelaskan bahwa jumlah isoglos yang membedakan daerah pengamatan 1-2 sebanyak 177 buah atau 63,44\%, daerah pengamatan 1-3 jumlah isoglos yang membedakan sebanyak 204 buah atau $71,11 \%$, daerah pengamatan 1-4 jumlah isoglos yang membedakan sebanyak 199 buah atau 71,32\%, daerah pengamatan 2-3 jumlah isoglos yang membedakan sebanyak 200 atau $71,68 \%$, daerah pengamatan 2-4 jumlah isoglos yang membedakan 
Mabasan 2007

sebanyak 212 atau 75,98\%, dan daerah pengamatan 3-4 jumlah isoglos yang membedakan sebanyak 215 atau 77,06\%. Hasil perhitungan dialektometri masing-masing daerah menunjukkan kategori beda dialek. Dengan demikian, dapat disimpulkan bahwa daerah pengamatan 1,2,3, dan 4 merupakan empat dialek yang berbeda dari satu bahasa. Terkait dengan hal tersebut, penggunaan metode kualitatif yaitu inovasi bersama dalam penelitian ini tidak diperlukan lagi karena berdasarkan perhitungan dialektometri tidak ditemukan suatu isolek yang terpisah dengan isolek lainnya sebagai bahasa yang berbeda. Hal ini juga sesuai dengan data di lapangan yang menganggap bahwa bahasa yang dituturkan pada keempat daerah pengamatan tersebut merupakan bahasa yang sama, yakni bahasa Bali. 


\section{Peta Bahasa dan Dialek-Dialek Bahasa Bali}

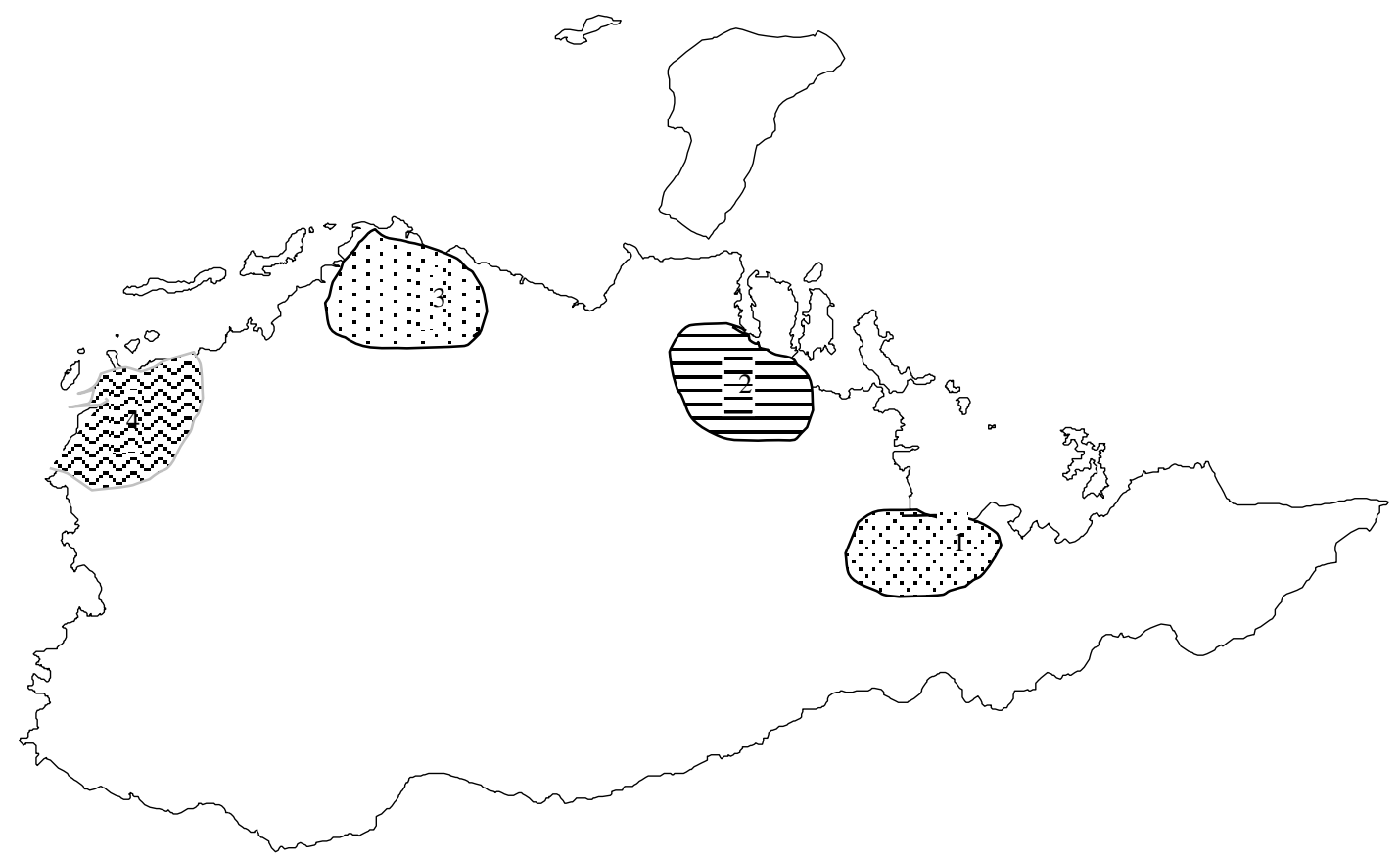

Keterangan : 1. Dialek Mekar Sari

2. Dialek Uma Sima

3. Dialek Rhee

4. Dialek Kokarlian

\subsection{Penentuan Status Kekerabatan}

Penentuan status kekerabatan dapat dilihat berdasarkan bukti kuantitatif dan bukti kualitatif. Bukti kuantitatif, yaitu berupa hasil perhitungan dialektometri, sedangkan bukti kualitatif dapat diperoleh dari inovasi bersama berupa korespondensi, variasi, dan leksikon.

Berdasarkan bukti kuantitatif, status kekerabatan keempat dialek di atas dapat dijelaskan sebagai berikut.

1. Daerah pengamatan 1, 2,3, dan 4 merupakan empat dialek yang berbeda.

2. Daerah pengamatan 1 lebih dekat ke daerah pengamatan 2 dari pada ke daerah pengamatan 3 dan daerah pengamatan 4. Hal ini 
dibuktikan dengan jumlah isoglos yang membedakan daerah pengamatan 1-2 yaitu sebanyak 63,79\%, lebih kecil bila dibandingkan dengan isoglos yang membedakan daerah pengamatan 1-3 yaitu sebanyak $73,11 \%$ dan daerah 1-4 sebanyak $71,32 \%$.

3. Daerah pengamatan 3 lebih dekat ke daerah pengamatan 1 dan 2 dari pada ke daerah pengamatan 4.Hal ini dibuktikan dengan jumlah isoglos yang membedakan darah pengamatan 3-1 dan 2, yaitu sebanyak $72,39 \%$, lebih kecil bila dibandingkan dengan isoglos yang membedakan daerah pengamatan 3-4, yaitu sebanyak $77,06 \%$.

4. Daerah pengamatan 4 lebih dekat ke daerah pengamatan 1 daripada ke daerah pengamatan 2 dan daerah pengamatan 3. Hal ini dibuktikan dengan jumlah isoglos yang membedakan daerah pengamatan 1-4, yaitu sebanyak $71,3 \%$, lebih kecil bila dibandingkan dengan isoglos yang membedakan daerah pengamatan 2-4, yaitu sebanyak 75,98\% dan daerah 3-4 sebanyak 77,06\%. Dari penjelasan di atas dapat dibuat pohon kekerabatan sebagai berikut. 


\section{BBS}

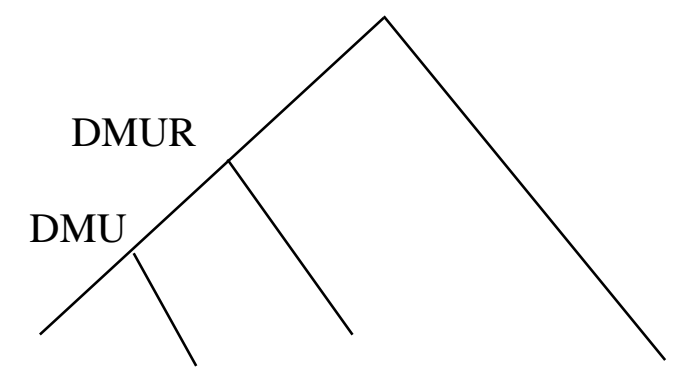

DM DU DR DK

Keterangan : BBS (Bahasa Bali Sumbawa)

DMUR (Dialek Mekar Sari, Uma Sima, dan Rhee)

DMU (Dialek Mekar Sari Uma Sima)

DM ( Dialek Mekar Sari)

DU (Dialek Uma Sima)

DR ( Dialek Rhee)

DK (Dialek Kokarlian)

\subsection{Jumlah Penutur Dialek-Dialek Bahasa Bali di Sumbawa}

Pada bagian sebelumnya telah dijelaskan bahwa bahasa Bali Sumbawa memiliki empat dialek, yaitu DM untuk daerah pengamatan 1, DU untuk daerah pengamatan 2, DR untuk daerah pengamatan 3, dan DK untuk daerah pengamatan 4. Pada bagian ini akan dipaparkan jumlah penutur yang ada pada masing-masing dialek tersebut.

DM adalah salah satu dialek bahasa Bali yang ada pada daerah pengamatan 1 di Kabupaten Sumbawa, yakni di dusun Mekar Sari, Desa Sepayung, Kecamatan Pelampang. Dialek ini mempunyai jumlah penutur sekitar 360 jiwa.

DU mempunyai jumlah penutur paling banyak, yaitu mencapai 844 jiwa. DU terletak pada daerah pengamatan 2, yaitu Kelurahan Uma Sima, Kecamatan Sumbawa, Kabupaten Sumbawa. 
DR berada di daerah pengamatan 3 di Desa Rhee, Kecamatan Rhee, Kabupaten Sumbawa. Dialek ini mempunyai jumlah penutur cukup banyak, yaitu mencapai 763 jiwa.

Di samping ketiga dialek tersebut di atas, ada dialek lain dari bahasa Bali, yaitu DK. Dialek ini berada pada daerah pengamatan 4. Daerah pengamatan yang berbeda dengan ketiga daerah pengamatan lainnya, yaitu terletak di Kabupaten Sumbawa Barat, yakni dusun Kokarlian, Desa Poto Tano, Kecamatan Seteluk. Dialek ini mempunyai jumlah penutur sekitar 153 jiwa.

\subsection{Pengenalan Dialek Bahasa Bali Sumbawa}

Deskripsi sistem fonologi dari salah satu dialek bahasa Bali, yakni Dialek Umasima (DU) diharapkan dapat memberi gambaran yang jelas tentang keadaan dialek, khususnya bidang fonologi. Deskripsi sistem fonologi DU mencakup inventarisasi dan distribusi fonem.

\subsubsection{Inventarisasi Fonem}

Fonem-fonem DU pada dasarnya dapat dikelompokkan menjadi dua bagian, yaitu vokal dan konsonan. Sistem vokal dialek ini tersusun dalam delapan vokal, seperti terlihat pada bagan berikut ini.

Depan Pusat Belakang

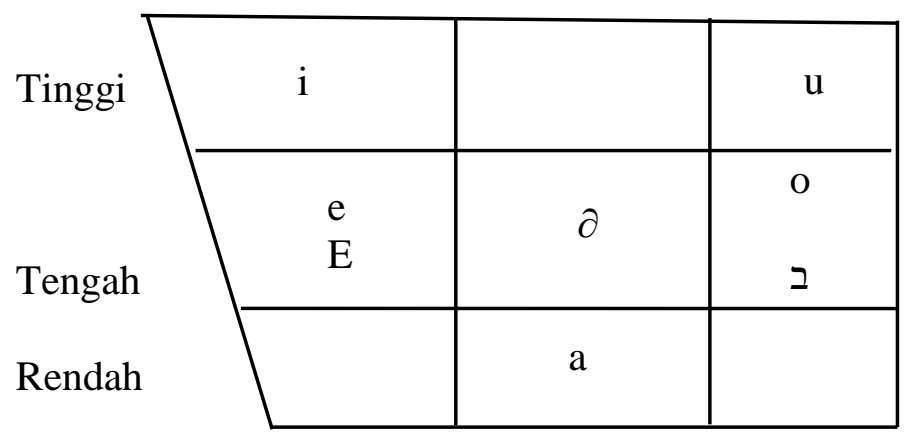

Bagan 1 Vokal Dialek Uma Sima 
Pembuktian akan status fonemis kedelapan vokal di atas dilakukan dengan menunjukkan pasangan minimal dari fonem-fonem tersebut. Untuk fonem-fonem yang tidak ditemukan pasangan minimalnya dilakukan dengan menunjukkan distribusi dari fonem-fonem tersebut, dengan catatan, bunyi bunyi yang memiliki distribusi yang lengkap atau unik, dianggap sebagai fonem yang berdiri sendiri, bukan alofon dari sebuah fonem (Mahsun, 2006:49-50).

Pembuktian akan status fonemis vokal-vokal DU di atas dapt dilihat pada pasangan minimal berikut ini.
a. /ə/ : apə 'ара'
/i/ : api 'api'
b. /i/ : təli 'kemaluan wanita'
/u/ : təlu 'tiga'
c. /E/ : bE 'daging'
/ee/ : bee 'bara'
d. /i/ : ciciך 'anjing'
/a/ : cacin 'cacing'
e. /o/ : sok 'bakul'
/ב/ : sבk 'periuk'

Pasangan minimal yang terdapat pada data (a), (b), (c), (d), dan (e) di atas menunjukkan bahwa bunyi /i/, /u/, /e/, /E/, /o/, /ב/, /a/, dan /כ/ masing-masing merupakan fonem yang berdiri sendiri.Vokal /i/ dan / $/ \mathrm{d}$, masing-masing memiliki alofon: /i/ dan /I/, seperti pada data berikut ini : [lipi] 'ular' dan [cərik] 'kecil', [kədIs] 'burung' dan [batIs] 'betis' dll. Alofon /i/ bisa muncul dalam silabe yang terbuka ataupun silabe yang tertutup sedangkan alofon /I/ hanya muncul pada silabe tertutp saja. Begitu pula fonem vokal /u/, yang memiliki alofon /u/ dan /U/. Alofon /u/ bisa muncul dalam silabe yang terbuka ataupun silabe yang tertutup, 


\section{Mabasan 2007}

sedangkan alofon /U/ hanya muncul pada silabe tertutup saja, seperti pada data berikut ini: [jagur] 'hantam', [məju] 'berak' dan [talUh] 'telur' Konsonan dalam dialek ini tersusun dalam sistem 19 buah fonem seperti pada bagan berikut ini.

\begin{tabular}{|c|c|c|c|c|c|c|c|c|c|}
\hline \multirow{3}{*}{ Jeni } & & \multicolumn{8}{|c|}{ Daerah Artikulasi dan Artikulator } \\
\hline & & \multirow{2}{*}{$\begin{array}{c}\text { Labial } \\
\text { La- } \\
\text { bial } \\
\end{array}$} & \multicolumn{2}{|c|}{ Dental } & \multicolumn{2}{|c|}{ Alveolar } & \multirow{2}{*}{$\begin{array}{c}\text { Palatal } \\
\text { Lami- } \\
\text { nal }\end{array}$} & \multirow{2}{*}{$\begin{array}{c}\text { Velar } \\
\text { Dor- } \\
\text { sal } \\
\end{array}$} & \multirow[b]{2}{*}{$\begin{array}{l}\text { Glo- } \\
\text { tal }\end{array}$} \\
\hline & & & $\begin{array}{l}\text { La- } \\
\text { bial }\end{array}$ & $\begin{array}{c}\text { Api- } \\
\text { kal }\end{array}$ & $\begin{array}{c}\text { Api- } \\
\text { kal }\end{array}$ & $\begin{array}{c}\text { Lami- } \\
\text { nal }\end{array}$ & & & \\
\hline \multirow{2}{*}{ Hambat } & $\mathrm{TS}$ & $\mathrm{P}$ & & & $\mathrm{t}$ & & $\mathrm{c}$ & $\mathrm{k}$ & $q$ \\
\hline & BS & $\mathrm{b}$ & & & $\mathrm{d}$ & & $\mathrm{j}$ & $\mathrm{g}$ & \\
\hline \multirow{2}{*}{$\begin{array}{c}\text { Geser/ } \\
\text { Frikatif/ } \\
\text { Spiran }\end{array}$} & $\mathrm{TS}$ & & & & & $\mathrm{S}$ & & & $\mathrm{h}$ \\
\hline & $\mathrm{BS}$ & & & & & & & & \\
\hline \multicolumn{2}{|c|}{ Nasal } & $\mathrm{m}$ & & & $\mathrm{n}$ & & $\tilde{\mathrm{n}}$ & $\eta$ & \\
\hline \multicolumn{2}{|c|}{ Lateral } & & & & 1 & & & & \\
\hline \multicolumn{2}{|c|}{ Getar } & & & & $\mathrm{r}$ & & & & \\
\hline \multicolumn{2}{|c|}{ Semivokal } & & $\mathrm{W}$ & & & & $\mathrm{y}$ & & \\
\hline
\end{tabular}

\section{Bagan 2 Konsonan Dialek Uma Sima}

Keberadaan fonem konsonan di atas dapat ditunjukkan masingmasing dengan pasangan minimal berikut ini.
a. /p/ : bapaq 'ayah'
/w/ : bawaq 'pendek'
b. /1/ : lipi 'ular'
$/ \mathrm{p} /$ : pipi 'pipi'
$/ \eta /$ : $\eta$ ipi 'mimipi (ber)'
c. /b/ : bəli 'abang'
/t/ : təli 'kemaluan wanita'
d. /d/ : adan 'nama' 
/w/ : awan 'awan'

a. $/ \mathrm{m} /$ : mani 'besok'

/j/ : jani 'hari ini'

b. /r/ : jagur 'hantam'

$/ t /$ : jagut 'janggut'

g. /s/ : basaך 'perut'

/j/ : bajaך 'muda'

h. /g/ : gigi 'gigi'

/s/ : gisi 'pegang'

i. /b/ : bəsəh 'bengkak'

/n/ : bənəh 'benar'

j. /b/ : bənəh 'benar'

/k/ : kənəh 'hati'

k. /m/ : mbבk 'kakak perempuan'

$/ \varnothing /$ : bבk 'rambut'

1. /s/ : siku 'siku'

/c,t/ : cikut 'tengkuk'

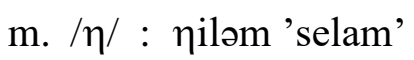

$/ \tilde{\mathrm{n}} /$ : ñiləm 'tenggelam'

n. /k/ : ken 'kepada'

$/ y /$ : yen' kalau'

o. /h/ : panah 'panah'

/k/ : panak 'anak'

Semua konsonan di atas tidak ada yang memiliki dua bunyi yang menjadi realisasinya. Mengenai fonem glotal /q/ yang hadir pada posisi akhir dan tengah tidak ditemukan pasangan minimalnya. Meskipun demikian, glotal tetap merupakan sebuah fonem yang sejajar dengan 
fonem konsonan lainnya seperti pada data berikut ini: [təฤaiq] 'siang' dan [daqak] 'miskin'.

\subsubsection{Distribusi Fonem}

Vokal-vokal dialek ini dapat menempati posisi awal, tengah, dan akhir. Untuk memperjelas ihwal distribusi vokal DU, berikut ini ditampilkan beberapa contoh.

/i/ : ipah 'adik dari istri', sirəp 'tidur', lipi 'ular'

/e/ : emas 'emas', bəleg 'licin', məsare 'baring'

/E/ : Eүsap 'lupa', kədEk 'tertawa', bE 'daging'

/a/ : ajak 'dengan', sipah 'ketiak', uwa 'kakaknya ayah/ibu'

/ə/ : əhsap 'lupa', pək 'dəkat', palə 'pundak'

/u/ : urip 'hidup', luh 'perempuan', məju 'berak'

/o/ : oña 'semua', toh 'kering', kebot 'kiri'

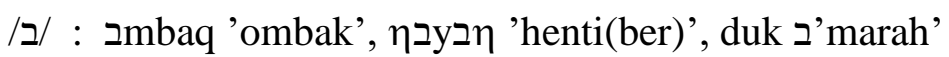

Konsonan-konsonan dalam dialek ini hampir semuanya dapat menempati posisi awal, tengah, dan akhir kata. Konsonan /w/, /y/, /j/, /c/, dan /ñ/ hanya dapat menempati posisi penultima dan antepenultima, sedangkan konsonan /h/ dan /q/ tidak pernah terdapat pada posisi antepenultima. Masing-masing contoh berikut ini diharapkan dapat memperjelas distribusi konsonan dalam dialek ini.

/b/ : bəleg 'licin', tibah 'mengkudu', raab 'atap'

/p/ : palə 'pundak', lipi 'ular', sirəp 'tidur'

/t/ : toh 'kering', batis 'kaki', sədユt 'hisap'

/d/ : dבn 'daun', adan 'nama', tukad 'sungai'

/c/ : cərik 'kecil', macə 'baca'

/k/ : kebot 'kiri', akah 'akar', panak 'anak'

/g/ : gədE 'besar', jagur 'hantan', bəleg 'licin'

/q/ : ququt 'urat', bawəq 'pendek' 
/s/ : sələm 'hitam', basaך 'perur', kəbus 'panas'

/h/ : pəhəs 'ludah', luh 'perempuan'

/m/ : mבkユh 'gemuk', gəməl 'genggam', guləm 'mendung'

/n/ : nipəh 'dengar', mani 'besok', diman 'cium'

/ñ/ : ñəmak 'ambil', puñan 'pohon'

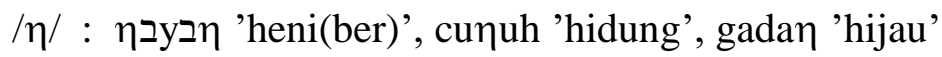

/1 / : liu 'banyak', bəleg 'licin', tugəl 'potong'

/r/ : rabun 'rabun', burבn 'binatang', añar 'baru'

/w/: waraך 'besan', bawəq 'pendek'

/y/ : yuyu 'kepiting', tiyuk 'pisau'

/j/ : jəmak 'ambil', ajak 'dengan', jani 'hari ini'

\section{Simpulan}

Bahasa Bali yang ada di Kabupaten Sumbawa dan Kabupaten Sumbawa Barat mempunyai empat dialek, yaitu dialek Mekar Sari (DM), dialek Uma Sima (DU), dialek Rhee (DR), dan dialek Kokarlian (DK). Adapun mengenai hubungan kekerabatan, DM memiliki hubungan kekerabatan yang dekat dengan DU, DR memiliki hubungan kekerabatan yang dekat dengan DM dan DU, sedangkan DK memiliki hubungan kekerabatan yang dekat. (dengan apa/belum jelas)

Berdasarkan data yang diperoleh, ternyata perbedaan linguistik cukup banyak ditemukan dalam bidang leksikon, yaitu 140 buah. Perbedaan fonologi adalah sebagai berikut.

a. Perbedaan fonologi yang berupa korespondensi ditemukan hanya satu korespondensi vokal, satu korespondensi konsonan yang berkategori sebagai korespondensi sempurna, dan lima korespondensi konsonan kurang sempurna. 
Mabasan 2007

b. Perbedaan fonologi yang berupa variasi vokal ditemukan sebanyak 50 buah dan variasi konsonsn ditemukan sebanyak 68 buah.

Dialek Mekar Sari (DM) mempunyai jumlah penutur sekitar 360 jiwa, dialek Uma Sima (DU) mempunyai jumlah penutur paling banyak yaitu mencapai 844 jiwa, dialek Rhee (DR) mempunyai jumlah penutur cukup banyak, yaitu mencapai 763 jiwa, dan dialek Kokarlian mempunyai jumlah penutur sekitar 153 jiwa. 


\section{DAFTAR PUSTAKA}

Bawa, I Wayan. 1983. Bahasa Bali di Bali: Sebuah Analisis Geografi Dialek. Jakarta: Universitas Indonesia (Disertasi Doktor).

Esser, S.J. 1938. Atlas van Tropisch Nederland. Batavia Centrum.

Herusantoso, Suparman dkk. 1987. Pemetaan Bahasa-Bahasa di Nusa Tenggara Barat. Jakarta: Pusat Pembinaan dan Pengembangan Bahasa.

Kersten,J. 1984.Tata bahasa Bali. Flores: Nusa Indah.

Mahsun. 1995. Dialektologi Diakronis: Sebuah Pengantar. Yogyakarta: Gadjah Mada University Press.

Mahsun, 2006. Kajian Dialektologi Diakronis Bahasa Sasak di Pulau Lombok. Metode Penelitian Kualitatif. Yogyakarta: Gama Media.

Mahsun, 2006. Distribusi dan Pemetaan Varian-Varian Bahasa Mbojo. Yogyakarta: Gama Media.

Mbete, Aron Meko. 1990. "Rekonstruksi Protobahasa Bali-SasakSumbawa'. Jakarta: Universitas Indonesia (Disertasi Doktor).

Nothofer, Bernd. 1981. Dialekktatlas von Zentral-Java. Wiesbaden: Otto Harrassowitz.

Sudika, I Nyoman. 1998. Isolek Bali di Lombok: Kajian dialektologi Diakronis. Denpasar: Universitas Udayana (Tesis).

Teeuw, A. 1958. Lombok: Een Dialect Geogrfische Studie. S'Gravenhage: Martinus Nijhoff.

Wacana, H.L. 1988. Sejarah Daerah Nusa Tenggara Barat. Proyek Inventarisasi dan Dokumentasi Kebudayaan Nusa Tenggara Barat. 